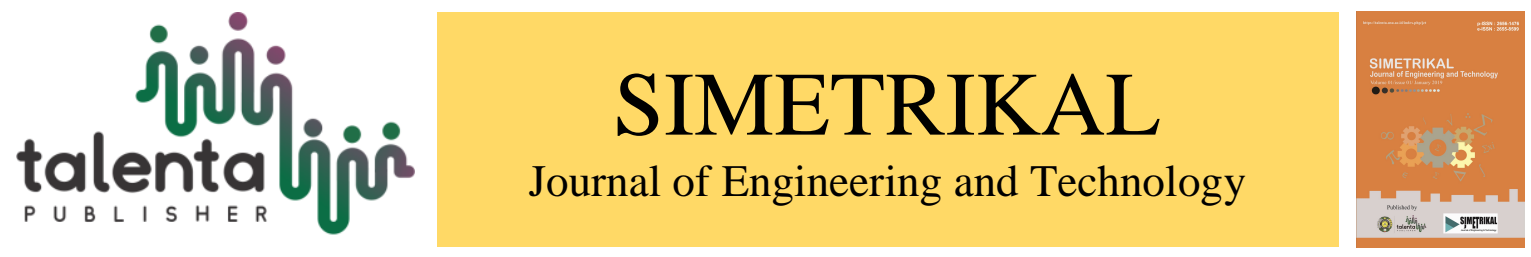

\title{
The Reinforcement Of Natural Rubber And Epoxidized Natural Rubbers With Fillers
}

\author{
Indra Surya ${ }^{1}$, Nabil Hayeemasae ${ }^{2}$ \\ ${ }^{1}$ Departement of Chemical Engineering, Faculty of Engineering, University of Sumatera Utara, \\ ${ }^{2}$ Department of Rubber Technology and Polymer Science, Faculty of Science and Technology, Prince of \\ Songkla University, Patani Campus, Pattani, Thailand
}

\begin{abstract}
The reinforcement of natural rubber (NR) and epoxidized natural rubbers (ENRs) with silica or carbon black (CB) by using a semi-efficient sulfur accelerated vulcanization system has been carried out. It was found that silica caused a longer in cure time compared to $\mathrm{CB}$ and due to the dissimilarity of their surface chemistry, it was also found that silica and CB caused the difference in reinforcement effect to those rubbers. Silica caused in filledvulcanizates of those rubbers with a higher modulus and lower tensile strength compared to their unfilled ones. On the other hand, CB caused enhancements in both modulus and tensile to those rubbers. The investigation on reinforcing efficiencies of those fillers on the rubbers found that the higher reinforcing efficiency of CB was attributed to its better degree of filler dispersion when compared to silica.
\end{abstract}

Keyword: Modulus, Reinforcing efficiency, Reinforcement, Tensile strength, Vulcanizate

\begin{abstract}
Abstrak. Penguatan Karet Alam (KA) dan Karet Alam Terepoksida (KAT) dengan menggunakan pengisi silika atau carbon black (CB) memakai sistim vulkanisasi belerang terakselerasi semi-effisien telah diteliti. Dimukan bahwa, silika menyebabkan perlambatan pematangan dibanding CB. Silika dan CB juga menyebabkan kenaikan perbedaan tork dan efek penguatan terhadap karet-karet tersebut. Silika menghasilkan vulkanisat-vulkanisat KA dan KAT terisi silika dengan modulus tarik yang lebih tinggi dan kekuatan tarik yang lebih rendah dibandingkan dengan vulkanisat-vulkanisat tidak berpengisi dari karet-karet tersebut. Sebaliknya, CB menyebabkan peningkatan-peningkatan modulus tarik dan kekuatan tarik. Pengamatan terhadap effisiensi penguatan yang dihasilkan oleh pengisi, ditemukan bahwa effisiensi penguatan yang lebih tinggi dari CB disebabkan oleh derajat penyerakan/dispersi yang lebih tingi dibanding dengan silika.
\end{abstract}

Kata Kunci: Modulus, Penguatan, Effisiensi penguatan, Kekuatan tarik, Vulkanisat

Received 15 November 2018 | Revised 25 January 2019| Accepted 31 January 2019

\footnotetext{
*Corresponding author at: Department of Chemical Engineering, University of Sumatera Utara, Jl. Almamater Kampus USU Medan, 20155, Sumatera Utara, Indonesia

E-mail address: indradanas@yahoo.com
} 


\section{Introduction}

Dried natural rubber (NR) is produced from the latex of the Hevea brasiliensis tree. Firstly before the process of coagulation, the latex was stabilized with suitable preservatives such as ammonia, formaldehyde, sodium sulfite and hydroxylamine which are added to produce technically-specified, constant viscosity grades of NR. NR contains 93 to $95 \%$ of cis-1, 4 polyisoprene as shown in Figure 1. NR is a non-polar rubber and mostly used in general purposes, industrial and engineering applications which include hoses, seals, sealant, O-rings, safety boots, tires, bushing and mountings materials.

Epoxidised natural rubber (ENR) has been launched into the rubber world as a chemically modified form of NR, in which some of the unsaturation is converted into epoxide groups which are randomly distributed along the NR chains as shown in Figure 2. Whenever NR is epoxidised, both its physical and chemical properties change according to the epoxidation degree. Commercially, ENR is available in $25 \mathrm{~mol} \%$ epoxidation (ENR 25) and $50 \mathrm{~mol} \%$ epoxidation (ENR 50). Many investigations on the preparation of ENR from NR latex and its characteristics have been reported and, practically up to $90 \mathrm{~mol} \%$ epoxidation is possible [1].

Increasing the degree of epoxidation increases the glass transition temperature $(\mathrm{Tg})$ which results in decrease resilience (more damping) and air permeability, increase hysteresis and betterwet traction. The epoxidation increases the polarity of the NR which improves its resistance towards hydrocarbon oils. ENR-25 and ENR-50 are strain crystallize [2], which reflected by their gum vulcanisates properties.

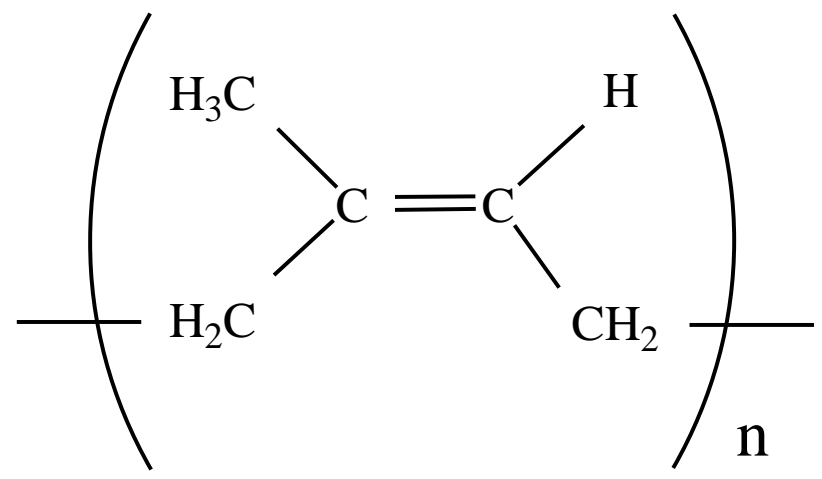

Figure 1 The molecular structure of natural rubber.

ENR, like NR, are cured by any sulphur accelerated vulcanisation system, but semi-efficient (Semi-EV) system or efficient (EV) system type formulation is preferred [2], [3]. In general, 
Semi-EV or EV vulcanisation of ENRs showed properties comparable to those of their NR counterparts. While Conventional (CV) system is not recommended for ENRs because of their poor ageing characteristics [4].

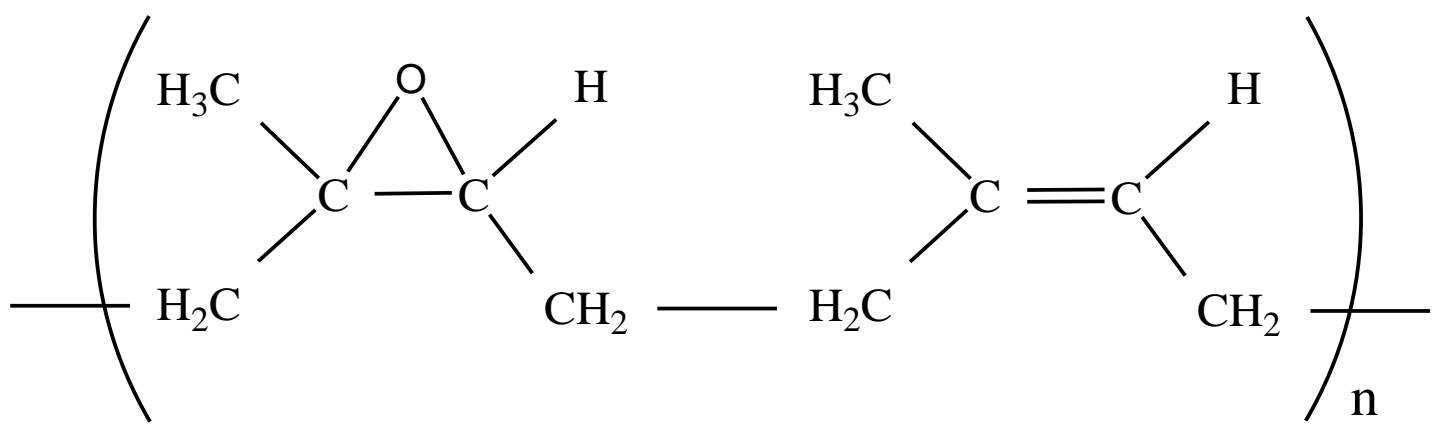

Figure 2 Molecular structure of epoxidised natural rubber.

Vulcanization is the chemical reaction which converts the weak, soft and plastic raw rubber into strong, hard and elastic rubber vulcanizate. The strength, hardness and elastic properties can be further enhanced through rubber reinforcement. Rubber reinforcement is the enhancement of mechanical properties such as hardness or stiffness and tensile and tear strengths due to the incorporation of a reinforcing filler [5]. Reinforcing fillers such as silica and carbon black (CB) are used to reinforce rubbers.

This research work investigated the effects of addition of silica or CB on cure characteristics and tensile properties of NR and ENRs compounds. The reinforcing efficiency of silica or CB on those rubbers is also reported.

\section{Materials and Methods}

\subsection{Materials}

NR grade SMR-L was obtained from Guthrie (M) Sdn. Bhd., Seremban, Malaysia. ENR 25 and ENR 50 were supplied by the Rubber Research Institute Malaysia (RRIM). Other compounding ingredients such as sulphur $(\mathrm{S})$, zinc oxide $(\mathrm{ZnO})$, stearic acid, $\mathrm{N}$-isopropyl-N'phenyl-p-phenylenediamine (IPPD), Mercapto benzothiazolyl disulphide (MBTS), precipitated silica (Vulcasil S) and N330 Carbon black were supplied by Bayer Co. (M) Sdn. Bhd., Petaling Jaya, Selangor, Malaysia. All materials were used as supplied.

\subsection{Compounding and cure characteristics}

A semi-efficient vulcanisation system was applied for the compounding. The compounding procedure was performed on a two-roll mill (Model XK-160). Table 1 displays the compound 
formulation of unfilled/filled NR and ENRs compounds. The compounding ingredients were mixed using a laboratory two-roll mill, Model XK-160. The cure characteristics of the unfilled rubbers compounds were determined at $150^{\circ} \mathrm{C}$ using a Monsanto Moving Die Rheometer (MDR 2000). The respective scorch time ( $\left.\operatorname{ts}_{2}\right)$, cure time $\left(t_{90}\right)$ and torque difference $\left(\mathrm{M}_{\mathrm{H}}-\mathrm{M}_{\mathrm{L}}\right)$ were obtained from the rheograph according to ISO 3417. The compounds were subsequently compression moulded using a stainless steel mould at $150{ }^{\circ} \mathrm{C}$ with a pressure of $10 \mathrm{MPa}$ using a laboratory hot-press based on the respective curing times.

Table 1 A semi-efficient accelerated sulphur vulcanization system

\begin{tabular}{cccc}
\hline Ingredients & $\mathrm{A}(\mathrm{phr} *)$ & $\mathrm{B}(\mathrm{phr})$ & $\mathrm{C}(\mathrm{phr})$ \\
\hline NR, ENR 25 or ENR 50 & 100 & 100 & 100 \\
ZnO & 5 & 5 & 5 \\
Stearic acid & 2 & 2 & 2 \\
IPPD & 2 & 2 & 2 \\
MBTS & 1.5 & 1.5 & 1.5 \\
Silica & 0 & 30.0 & 0 \\
CB N330 & 0 & 0 & 30.0
\end{tabular}

*parts per hundred rubber

\subsection{Tensile properties}

Dumbbell-shaped samples were cut from the moulded sheets. Tensile tests were performed at a cross-head speed of $500 \mathrm{~mm} / \mathrm{min}$ using an Instron 3366 universal tensile machine according to ISO 37. The tensile strength (TS) and stress at 100\% elongation (M100), stress at 300\% elongation (M300) and elongation at break (EB) were investigated.

\section{$3 \quad$ Results and Discussion}

\subsection{The cure characteristics}

\subsubsection{The effects of silica additions}

The effects of silica and CB additions on cure characteristics of NR and ENR are shown in Table 2. As shown, the additions of silica into those rubbers compounds caused in silica-filled rubber vulcanizates with longer scorch and cure times (column B) compared to their unfilled 
vulcanizates (column A), some cure retardations happened. It was due to the reaction between the silica filler with zinc oxide during vulcanization [6], [7]. The silica-zinc oxide intermediate compound could not activate the MBTS accelerator and hence, the vulcanization rate was retarded.

Table 2 The cure characteristics of unfilled and filled rubbers vulcanizates

\begin{tabular}{|c|c|c|c|c|c|c|c|c|c|}
\hline \multirow{2}{*}{ chare } & \multicolumn{3}{|l|}{ NR } & \multicolumn{3}{|c|}{ ENR 25} & \multicolumn{3}{|c|}{ ENR 50} \\
\hline & A & B & $\mathrm{C}$ & A & B & $\mathrm{C}$ & A & $\mathrm{B}$ & $\mathrm{C}$ \\
\hline Scorch time, minute & 4.36 & 5.48 & 2.78 & 2.54 & 7.19 & 1.63 & 2.40 & 7.23 & 2.36 \\
\hline Cure time, minute & 6.77 & 13.91 & 6.43 & 5.59 & 11.87 & 4.56 & 5.43 & 15.34 & 5.20 \\
\hline Maximum & 4.88 & 6.03 & 8.80 & 6.77 & 9.08 & 13.24 & 6.54 & 11.71 & 10.67 \\
\hline dN.m & 0.07 & 0.61 & 0.24 & 0.07 & 0.23 & 0.09 & 0.03 & 0.07 & 0.05 \\
\hline $\begin{array}{l}\text { Minimum torque, } \\
\text { dN.m }\end{array}$ & 4.81 & 5.42 & 8.56 & 6.70 & 8.85 & 13.15 & 6.51 & 11.64 & 10.62 \\
\hline Max. torque minus & & & & & & & & & \\
\hline Min. torque, dN.m & & & & & & & & & \\
\hline
\end{tabular}

The additions of silica caused silica filled vulcanizates with higher torque differences compared to their unfilled ones. It was due to reinforcing effects reinforcing of silica filler and also the formation of physical crosslinks which was formed by rubber to filler interaction [8]. These physical crosslinks and sulphide crosslinks contribute to total crosslink density [9]. The total crosslink density of a rubber vulcanizate can be measured qualitatively from its value of torque difference [10].

\subsubsection{The effects of $\mathrm{CB}$ additions}

The additions of CB filler on the three types of rubbers compounds caused in CB-filled rubbers vulcanizates with shorter scorch and cure times (column C). Some cure enhancements have happened. According to Fetterman [7], CB filler interacted with sulphur during vulcanization and crosslinked the chains of rubbers. Similar to the silica additions, CB also caused 
in CB-filled vulcanizates with higher torque differences. It was due to the formation of physical crosslinks as the consequence of $\mathrm{CB}$ filler to rubbers interactions.

\subsection{The tensile properties}

\subsubsection{The effects of silica additions}

The effects of silica additions on tensile properties of NR and ENRs compounds are shown in Table 3. As can be seen, Silica caused in silica-filled NR and ENRs vulcanizates with a higher M100 and M300. Surely, it was due to the rubber - filler interaction which decreased the mobility of the rubbers chains [11] and formed physical crosslinks [12]. As previously discussed, the physical crosslinks affected the total crosslink density. According to Boonstra [13], any increase in crosslink density will increase the tensile modulus of a rubber vulcanizate and hence, it can be considered that the silica additions its effect was the same with increasing in crosslink density. It was in line with the value of torque differences in Table 2 which presents that torque differences of silica-filled vulcanizates were higher than those of the unfilled ones.

The tensile strengths of silica-filled rubbers vulcanizates were lower than those of unfilled ones. Decreases in tensile strength were due to the strain-induced crystallization phenomenon which causing the filled vulcanizates broke at lower elongations [14].

Table 3 The tensile properties of unfilled and filled rubbers vulcanizates.

\begin{tabular}{|c|c|c|c|c|c|c|c|c|c|}
\hline Vulcanizate & NR & & & ENR & & & ENR & & \\
\hline Tensile properties & A & B & $\mathrm{C}$ & A & B & $\mathrm{C}$ & A & $\mathrm{B}$ & $\mathrm{C}$ \\
\hline M100, Mega Pascal & 0.51 & 0.91 & 1.19 & 0.69 & 0.92 & 1.87 & 0.67 & 1.41 & 1.91 \\
\hline M300, Mega Pascal & 1.16 & 2.49 & 5.34 & 1.57 & 2.73 & 7.88 & 1.15 & 4.42 & 7.23 \\
\hline TS, Mega Pascal & 18.1 & 16.2 & 21.8 & 23.3 & 16.8 & 27.4 & 20.5 & 17.4 & 21.9 \\
\hline $\mathrm{EB}, \%$ & 1231 & 1069 & 851 & 1139 & 870 & 669 & 1108 & 776 & 628 \\
\hline
\end{tabular}

The additions of silica caused in decreases in elongations at break. It was due to decreasing in the extensibility of the rubbers vulcanizates. 


\subsubsection{The effects of $\mathrm{CB}$ additions}

The additions of CB filler not only caused an improvement in tensile modulus but also an improvement in tensile strength. The tensile modulus improvement was due to the rubbers - filler interactions and the tensile strength improvement was due to the reinforcing effect of the filler to the rubbers compounds. Much different with silica, the CB filler - rubbers interactions were adhesion interaction type and it was stronger. The stronger filler - rubber interaction, the higher was the tensile strength of a rubber vulcanizate.

\subsection{The reinforcing efficiency}

Reinforcing efficiency (RE) which is provided by reinforcing filler can be calculated using Equation 1 [15].

$$
\mathrm{RE}=\left(\mathrm{M} 100_{\mathrm{f}}-\mathrm{M} 100_{\mathrm{uf}}\right) / \mathrm{M} 100_{\mathrm{uf}}
$$

where: $\mathrm{M} 100_{\mathrm{f}}=\mathrm{M} 100$ of filled vulcanizate

$$
\mathrm{M} 100_{\mathrm{uf}}=\mathrm{M} 100 \text { of unfilled vulcanizate }
$$

RE can be also calculated based on torque properties by using Equation 2 .

$$
\mathrm{RE}=\left(\mathrm{M}_{\mathrm{f}}-\mathrm{M}_{\mathrm{uf}}\right) / \mathrm{M}_{\mathrm{uf}}
$$

where: $\mathrm{M}_{\mathrm{f}}=$ (Maximum torque - Minimum torque) of filled vulcanizate

$$
\mathrm{M}_{\mathrm{uf}}=\text { (Maximum torque }- \text { Minimum torque) of unfilled vulcanizate }
$$

A higher RE indicates a stronger rubber to filler interaction which is influenced by the degree of filler dispersion. The degree of filler dispersion in the rubber phase was determined by Equation $3[16]$.

$$
\mathrm{L}=\eta_{\mathrm{r}}-\mathrm{m}_{\mathrm{r}}
$$

where: $\eta_{\mathrm{r}}=\left[\mathrm{ML}_{\mathrm{f}} / \mathrm{ML}_{\mathrm{uf}}\right]$ and $\mathrm{m}_{\mathrm{r}}=\left[\mathrm{MH}_{\mathrm{f}} / \mathrm{MH}_{\mathrm{uf}}\right]$, where $\mathrm{ML}_{\mathrm{f}}$ and $\mathrm{MH}_{\mathrm{f}}$ are the minimum and maximum torques of the filled vulcanizate; and $\mathrm{ML}_{\mathrm{uf}}$ and $\mathrm{MH}_{\mathrm{uf}}$ are the minimum and maximum 
torques of the unfilled vulcanizate. A lower value of $\mathrm{L}$, at a particular loading, means a better degree of filler dispersion.

RE and degree of filler dispersion of silica and CB on NR and ENRs are shown in Table 4. As shown, silica has the highest RE when it used to reinforce ENR 50. It was due to the polarity of the rubber. ENR 50 has the highest degree of polarity compared to others rubbers compounds and hence, it's interaction with silica was the strongest one. Stronger filler to rubber interaction makes the filler can be dispersed readily inside the rubber phase. This explanation is in line with the lowest value of L of silica for ENR 50 (see Table 4). On the other hand, silica has the lowest RE when it used to reinforce NR. It was due to the incompatibility interaction between the NR and silica. The hydrophilic silica tent to form a larger agglomerate which poor the degree of filler dispersion and hence, causing in the highest $\mathrm{L}$ value of silica for NR.

The RE and L value of silica for ENR 25 were between those of NR and ENR 50. Again, it was due to the polarity degree of ENR 25 which is between NR and ENR 50.

The CB filler has the same trend with silica whenever it was used to reinforce those rubbers. It has the highest RE and degree of filler dispersion for ENR 50. It was due to its nature of rubber filler interaction. The active functional groups of CB such as carboxyl, carbonyl, etc. can interact readily and strongly with the most polar rubber (ENR 50). On the other hands, CB filler has the lowest RE and degree of filler dispersion for NR.

Table 4 The reinforcing efficiency and L values of silica and carbon black

\begin{tabular}{ccc}
\hline Rubber vulcanizates & $\mathrm{RE}=\left(\mathrm{M}_{\mathrm{f}}-\mathrm{M}_{\mathrm{uf}}\right) / \mathrm{M}_{\mathrm{uf}}$ & $\mathrm{L}$ \\
\hline Silica-filled: & 0.13 & 7.5 \\
NR & 0.32 & 1.9 \\
ENR 25 & 0.78 & 0.5 \\
ENR 50 & $\mathrm{RE}=\left(\mathrm{M} 100_{\mathrm{f}}-\right.$ & \\
CB-filled: & $\left.\mathrm{M} 100_{\mathrm{uf}}\right) / \mathrm{M} 100_{\mathrm{uf}}$ & 1.6 \\
NR & 1.33 & 0.67 \\
ENR 25 & 1.71 & 0.04 \\
ENR 50 & 1.85 & \\
\hline
\end{tabular}




\section{Conclusions}

From this study, the following conclusions were drawn:

1. Silica caused improvement in tensile modulus but deterioration in tensile strength for natural rubber and epoxidised natural rubbers compounds.

2. Carbon black caused improvements in both tensile modulus and tensile strength for natural rubber and epoxidised natural rubbers compounds.

3. Reinforcing efficiency and degree of filler dispersion of carbon black were higher than those of silica for natural rubber and epoxidised natural rubbers compounds.

\section{REFERENCES}

[1] T. Miyashita, "Prog. Polym. Sci.," Prog. Polym. Sci., 1993.

[2] T. D. Gazeley, K.F., Gorton, A.D.T. and Pendle, "Natural rubber science and technology," in Oxford science publications, 1988.

[3] C. S. L. Baker, I. R. Gelling, and R. Newell, "Epoxidized Natural Rubber," Rubber Chem. Technol., 1985.

[4] C. S. L. Baker, I. R. Gelling, and A. Samsuri, "Epoxidised Natural Rubber," J. Nat. Rubber Res., 1986.

[5] I. Surya, Polym Test, Vol 40. 2014.

[6] R. Mukhopadhyay, S. K. De, and S. N. Chakraborty, "Effect of vulcanization temperature and vulcanization systems on the structure and properties of natural rubber vulcanizates," Polymer (Guildf)., 1977.

[7] M. Q. Fetterman, "PRECIPITATED SILICA - COMING OF AGE.," Rubber World, 1986.

[8] R. C. R. Nunes, J. L. C. Fonseca, and M. R. Pereira, "Polymer-filler interactions and mechanical properties of a polyurethane elastomer," Polym. Test., 2000.

[9] K. E. Polmanteer, "Reinforcement Studies - Effects of Silica Structure on Properties and Crosslink Density.Pdf," Rubber Chemistry and Technology. 1975.

[10] H. Cochrane and C. S. Lin, "The Influence of Fumed Silica Properties on the Processing, Curing, and Reinforcement Properties of Silicone Rubber," Rubber Chem. Technol., 1993.

[11] E. M. Dannenberg, "Filler Choices in the Rubber Industry," Rubber Chem. Technol., 1982.

[12] G. Kraus, "Reinforcement of elastomers by carbon black," Die Angew. Makromol. Chemie, 1977.

[13] B.B. Boonstra, Carbon black and non black in Rubber Technology. New York: Van Nostrand Reinhold Company, 1978.

[14] C. K. L. Davies, S. V. Wolfe, I. R. Gelling, and A. G. Thomas, "Strain crystallization in random copolymers produced by epoxidation of cis 1,4-polyisoprene," Polymer (Guildf)., 1983.

[15] A. S. Hashim, B. Azahari, Y. Ikeda, and S. Kohjiya, "The Effect of Bis(3Triethoxysilylpropyl) Tetrasulfide on Silica Reinforcement of Styrene-Butadiene Rubber," Rubber Chem. Technol., 1998.

[16] B. L. Lee, "Reinforcement of Uncured and Cured Rubber Composites and Its Relationship to Dispersive Mixing-An Interpretation of Cure Meter Rheographs of Carbon Black Loaded SBR and Cis-Polybutadiene Compounds," Rubber Chem. Technol., 1979. 
